\title{
Water Crisis as a Security Issue: Water Securitization in People's Republic of China
}

\author{
Gita Karisma ${ }^{1, *}$ Hasbi Sidik $^{2}$ \\ ${ }^{1,2}$ International Relations Department, Universitas Lampung \\ *Corresponding author. Email: gita.karisma@fisip.unila.ac.id
}

\begin{abstract}
The global water crisis has caused a wide range of problems. Several studies focus on the worldwide distribution of water and its impact on economic sector, human health, and the social and political aspect. However, This study then discusses the water crisis as a security issue in China by exploring policies and projects in China toward water crisis. There are a tendency, The state is the primary actor in any securitization process then water issue might be turned into an national security problem. This article uses qualitative approach with document as the secondary data. This article finds that securitization process in People's Republic of China (PRC) is essentially a state-centred project, which means that the state plays an important role in securitizing issue. The securitizing actor, the People's of Republic of China government, takes a speech act on water issue. The government also implement a strict control to support its water policies.
\end{abstract}

Keywords: Water Crisis, Water Scarcity, Securitization, China

\section{INTRODUCTION}

The water crisis is a problem that is increasingly attracting worldwide attention. Significantly, when the water crisis has become a world problem that is quite alarming and frightening. The drought has been widespread and has subsequently given rise to the socalled global water crisis

There's evidence to support the alarmists. An estimated one billion people -- that's one out of every seven people -- don't have daily access to safe drinking water, according to One Drop, an international water-rights advocacy group. An additional 2.5 billion people lack basic sanitation, and increased industrialization in developing countries like China, India, Brazil, and sub-Saharan Africa has resulted in severe pollution of once-viable sources of fresh drinking water [1].

The Food and Agriculture Organization (FAO) has long been highlighting the problem of the water crisis about 30 years ago in commemoration of World Food Day. FAO also raised the theme Water for life with an emphasis on global water management. This water crisis is causing severe problems in several parts of the world. Lebanon, Syria, Turkey, which used to be quite fertile, are currently being hit by forced migration of hundreds of thousands of refugees due to the water crisis [1].
Bolivia, which has almost succeeded in producing all its own food, now has to import an ample food supply due to drought, flooding and government policies. In 2009, the Department of Environmental Protection (MEP) notify that, on average, about $43 \%$ of the water in China's seven major rivers is not healthy for human consumption [2]. Moreover, Scientists also predict, in the United States, high temperatures and infrequent rainfall will cause droughts to get worse, as is the case now in the west of America. Even desert cities like Tucson, Las Vegas, and Phoenix may become unlivable in the future [1].

The People's Republc of China (PRC) water crisis is becoming an interesting case, where an authoritarian state rules water securitization. Some of the main environmental problems in China are related to land degradation, over-exploitation and pollution of water resources, and subsidence of ground water from groundwater inlets, which threaten ecosystems and human activities. China has adopted land conservation and reduced groundwater use as part of a water-saving strategy. Carole Dalin wrote an article about Balancing water conservation and food security in China. It discusses the problem of reducing irrigation especially in arid regions, Inner Mongolia and the Beijing region. This paper also discusses the limitations of fresh water in the Chinese region requiring land conversion from 
rain-fed agriculture and irrigation. China will increase $14.8 \mathrm{~km} 3 /$ year of irrigation while increasing national crop income (+1\%, IM+B scenario) [3].

There is an article that analyzes the water quality security issue in China, especially the factors that affect it and proposes some targeted measures. In China, with its outstanding water environment issues, water shortages caused by poor water quality have hampered development. This article underscores that industry and economic development have developed rapidly, but on the other hand, sewage treatment facilities are inadequate. Apart from the extensive use of pesticides and fertilizers, there are other main factors contributing to the deteriorating air in rural China, namely pathogenic microorganisms, harmful disinfection products, organic contaminants [4]. Another article focus on a connection between water and energy for development. There is a complex relationship between water and coal, where the activity of burning coal for electricity has increased the demand for water [5]. This is involved in the process of extraction, transportation, cooling and pollution issues, which cause greenhouse gases in the atmosphere which in turn affects the hydrological cycle and the availability of drinking water and water for agriculture. Thus, it must be mediated beetween demands for industrial development and economic security economics, on the one hand, and for environmental security, on the other hand, present increasing challenges for government [5]

Itay Fischendler looks systematically at the missing gaps around the securitization discussion. Several things that need to be considered in the securitization analysis are structural mechanisms such as setting up buffer zones around water infrastructure; institutional models and exclusion of civil society from decision-making processes; including linguistic issues such as the use of narratives and framing symbols to justify military involvement [6]. Discourse securitization may not be evenly distributed in space and time, because there is always the possibility of being influenced by situations and conditions such as natural disasters, resource scarcity, and asymmetric power [6]. However, the articles above have not discussed in term of the state's water securitization practices in detail. This article elaborates water securitization particularly in China.

\section{THEORETICAL REVIEW}

Constructivists argue that security and threats are socially constructed. Thus, the meanings of security and threats change according to the context, and therefore, meaning exists because we have asked that it must have a form [7]. Moreover, Securitization can be said to be a process of turning an issue into a security problem. Securitization can be interpreted as an extreme form of politicization [8]. There are several vital concepts in the framework of understanding securitization, namely ideas that show how actors perform securitization and consist of securitizing actors, speech acts, existential threats, referent objects, and audiences [8].

First, the securitizing actor is the actor who portrays securitization. In this case, Waever explains that the power holders who determine as securitizing actor who the most are. Second, the speech act is a step or effort taken by the securitizing actor either through socialization or others in securitizing an issue. The third is an existential threat, namely problems or threats discoursed and considered dangerous. Existential threats are very diverse and different depending on the case, whether the environment or society. Fourth is the referent object. The securitization process will depend on the condition of the referent object or who is being threatened either directly or indirectly, and this will vary in each case. The fifth concept is the audience condition where the affected parties believe or not to the issue that is indeed an existential threat. From the explanation above, it can be understood that securitization is said to be successful if the speech act is successful or the audience accepts the socialization of ideas. In other words, the audience agrees that the issue raised is an existential threat that threatens their country and community.

Generally, the state is the primary actor in any securitization process. Securitization in Asia is essentially a state-centred project, which means that the state plays an important role in deciding which issues are to be securitized, when to be securitized, and what method of securitization, whether it will be principally a rhetorical speech act, or carried out through concrete policies and institutional adjustments [9] There are some specific explanations below, how it runs in China as an Asian country.

\section{METHOD}

This research uses a qualitative approach where secondary data is obtained from official sources, reports, and news regarding the water crisis, environmental issues, and water security policies. The initial data is the impact of the water crisis on human health and ecological problems from Water Global Resource. This data informs the water crisis in various dimensions and its relationship to environmental issues. Furthermore, the water crisis and environmental problems interconnectedness is understood through data on the water crisis in China and the South-North Water Transfer (SNWTP) Project program. Finally, the condensation of the above data is presented and concluded in an inductive process that is inherent in qualitative 


\section{RESULT AND ANALYSIS}

\subsection{Water Crisis}

According to Global Water Resources, based on observations over the last twenty years, several problems related to the water crisis include; [10].

- Clean water sources are not distributed in a balanced way. Many rivers can be good sources of water flowing in areas many people do not inhabit, but water sources are far from residential.

- Most of the clean water that people need is groundwater.

- About $75 \%$ of the water focuses on agricultural purposes. The remaining $20 \%$ is for industrial use, and the last $5 \%$ is for domestic use.

- By 2025, The Global Water Resource predicts that 29 countries will experience water scarcity.

- One of the water fundamental problems is the scarcity of water and the difficulty of getting clean water that is safe to drink or for sanitation purposes, especially in developing countries where many people still suffer from diseases caused by polluted water.

In addition, Global Water Resources also noted that the water crisis does not only affect human health but is quite closely related to environmental problems, namely;

- Industrial development and land clearing have an impact on ecosystem destruction.

- Eutrophication occurs, namely seawater pollution in the form of increasing harmful nutrients to threaten the wealth of marine habitats [11]. This seawater pollution generally comes from waste that is on land and then carried by seawater currents. The effect can be in the form of depletion of seawater oxygen and the proliferation of algae which is quite dangerous for animals living in the sea. It says that eutrophication threatens the sustainability of the wealth of marine organisms.

- The lack of the richness of marine habitats possibly affect fisheries, for example, the reduced fish catch of fishermen

- It can affect sea-level rise, which in turn also affects the environment. Areas that have a lot of water or coastal areas that also depend on livelihoods or food sources from the sea are more vulnerable

As described above, we realize that the water crisis is also related to environmental pollution problems, such as increasing urbanization. The industrialization process also drives a massive demand for water. Other causes, namely poor land management and factory waste such as plastic disposal, also contribute to the scarcity of clean water. Based on the grounds of the water crisis described by Global Water Resources above, the water crises problems consist of at least two issues. First, the natural water crisis droughts such as the lack experienced. Second, the water crisis due to industrial waste. Water crisis caused by water pollution, causing lack of clean water. These are also happened in China. As the country with the largest population, China has only $6 \%$ of the world's total freshwater resources. In 2014, statistics of the World Bank shows that the total renewable water resources per inhabitant is only 2,018 meters each year- this number is $75 \%$ less than the global average [12].

From the description above, it is pretty clear that the problem of the water crisis has tendency to become a water security issue. The water crisis is closely related to food scarcity and hunger, which of course, are problems that are near related to human security. A report from Oxfam estimates that the average cost of staple foods will increase by $180 \%$ by 2030 , primarily due to water shortages [12]. But further than that, the water crisis can also become a national security problem because water is needed to support domestic production processes - such as oil which, if not taken care of, the water crisis can become a source of the struggle between countries in the world. For this reason, the water crisis will attract the state's interest to protect its water sources as much as possible. It means that the state, China in this case, can make efforts to securitize the limited water sources.

\subsection{Water Security}

The United Nations Environment Program (UNEP) defines water security as: [10]

"...water security represents a unifying element supplying humanity with drinking water, hygiene and sanitation, food and fish, industrial resources, energy, transportation and natural amenities, all dependent upon maintaining ecosystem health and productivity"

From the above definition, it cannot be denied that water is also needed for agriculture and industry apart from being an individual human need. This water crisis becomes even more interesting when you see that the water crisis can cause conflict. From its nature, water can at least be classified, namely first, water that does not move like a lake, and second, water that moves like a river. Gleick (1993) [13]. argues that the issue that should be discussed more is determining when and where conflicts caused by resource problems can break out rather than debating whether environmental topics can contribute to the instability of a country or region or 
war [13]. Conflicts may occur on a small scale, such as inter-regional or rural riots (due to fighting over water resources), border conflicts between countries, or disharmony frictions between countries that do not directly border each other. Gleick sees threats to environmental security as a mixture of sociopolitical, economic and cultural factors. Gleick's argument also forms the basis for some of the views mentioned above-according to Gleick, four characteristics make water a source of strategic competition, namely a) how scarce water is; b) to what extent the water is sufficient for the needs of several countries; c) the relative power of the countries in the river basin; d) ability to access alternative water sources [13]. In the same view, a series of articles on $\mathrm{Hu}$ Jintao's military thinking identified the occurrence of "sudden emergencies" as the link between traditional and non-traditional security in, for example, large-scale environmental crises, such as the scarcity of water, can be at the heart of interstate wars [14].

China's water security have become clear. Climate change will also increase China's vulnerability to water scarcity. A three-year survey of river systems completed by Beijing in 2013 showed that the number of rivers in China had decreased by 28,000 from previous estimates [15]. The flow of the Yellow River, which provides water for most of China's population, is a tenth of what it was 80 years ago. In addition, groundwater aquifers, which are very important for northern China, are being drained at a rate of 1 to 3 meters per year [15]. Then, Among several contributing factors affect inherent water insecurity, the reality of low per capita water availability due to population growth cannot be ignored [16].

\subsection{The Securitization of Water in People's Republic of China}

The next issue of the water crisis related to the security framework is the debate about whether or not desecuritization or securitization is necessary and the factors behind it. One example of when the state securitizes the water crisis is what the Chinese government does. China is pursuing the Military-Civil Fusion (MCF) Development Strategy Development Strategy to "unify" its economic and social development strategy with its security strategy to build an integrated national strategy system and capability to support China's national rejuvenation goals [17]. Central government of People's Republic of China plays an important role in securitizing water issue with both principally a rhetorical speech act, and carried out through concrete policies and institutional adjustments.

The problem of the water crisis in China continues to this day. Water problems arise due to drought, low rainfall, water pollution and development problems. China has experienced abnormally dry weather in recent years, especially in October 2017 until February 2018, no rainfall, including rain and snow, was recorded in the Beijing. The poor management has made the water crisis worse. It is also estimated that $70 \%$ of China's rivers and lakes are polluted [18]. In addition, it has been noted that $80 \%$ of water is concentrated in South China, but in fact the North needs more water due to population and development driven water demand considerations. It is more complicated when in 2014, President Xi Jingping initiated Jing Jin Ji Project which is integrates the three highly industrialized Northern provinces - Beijing, Tianjin and Hebei - as a single megalopolis having a combined total area population of 130 million, where the water availablity for consumption annually per person in three provinces are around below 184 cubic meters (Hubei is below 100). As described by the China Statistical Yearbook (CSY), it is far below the 500 cubic meters of water scarcity standards [19]. In fact, Two-thirds of the cities in China face water shortage; more worryingly, in a number of cities, groundwater used for consumption is also frequently contaminated [20].

The PRC government realizes that water scarcity is one of the consequences of economic development, namely industrialization in China [2]. On the one hand, the development of automation has made the demand for water in China also increase. On the other hand, the industry has also resulted in water pollution. Beijing and North China are regions that are currently experiencing a moderately severe drought problem. To overcome this, China built dams and canals to flow water from south to north. It is known as the South-North Water Transfer (SNWTP) Project.

The SNWTP project was proposed in 1952 to reduce water shortages in North China. Construction of the project started in 2002 and is expected to end in 2050. The project involves three phases with routes in the west, east and centre of China, which will eventually transfer 36 billion cubic meters of water per year from South to North [2]:

- The eastern line is expected to be completed in 2014 and will transport 14.8 billion $\mathrm{m} 3$ from the southern Yangtze for $1,156 \mathrm{~km}$ to the provinces of Jiangsu, Anhui, Shandong and Hebei, as well as the city of Tianjin

- The middle line is expected to be completed in 2014 and will transport 13 billion $\mathrm{m} 3$ from the 1,267 km Danjiankou Reservoir to Hubei, Henan and Hebei provinces.

- Now, The East and Middle routes- each taking 10 years to build- have been in service since 2013 and 2014 respectively and are capable of transferring 20.9 billion cubic meters of water each year.

- The western line is expected to be completed by 2050 and will transport 8 billion $\mathrm{m} 3$ of three tributaries approximately $500 \mathrm{~km}$ from the 
Yangtze to the provinces of Gansu, Qinghai, Shaanxi, Shanxi, Inner Mongolia and Ningxia

The PRC government oversees the process of developing and regulating the water crisis. The state controls the use of dam water in the south so that there is no shortage of water to flow to the north. In this case, Beijing has begun to monitor the community through stricter regulations and punishing abuse of land and tap water supplies. An example, Qingdao, Shenzhen and Liaoning provinces have banned the use of highly hazardous phosphate detergents [21].

The Chinese Communist Party issued speech act for example, by creating the poster bearing the slogan "kangzai liqiang, gang kuai de tigao shengchan he shenghuo shuiping (抗灾力强, 更快地提高生产和生 活水平)” [22]. which roughly means (by) strengthening defence against natural disasters, improving living standards and accelerating production. In Xin Jinping era, the gravity of this issue did not go away when he spoke in 2013 that "the standard that internet users set for lake water quality is whether the mayor dares to jump in and swim" [18].

The SNWPT project also led to the forced displacement and eviction of residents. There were about 330,000 people forced to move due to the development of Danjiangkou reservoir on the Middle Route [23]. The Forced displacement is typically of the command system in communist state, where the distribution of natural and human resources was manipulated by the government to maximize national interests while sacrificing individual rights [23]. Pollution and environmental protests are increasing especially in response to construction project in west and the middle route. However, the people has less power and remains obedient to the govermenment. Dr. Junjie Zhang, an environmental economist at Duke Kunshan University in China, explains that "Since 2013, China has had very tight control over the issue of air pollution, and many pollutants have peaked." [18]

The progress and development of cities in China causes the demand for water to increase, so that technological breakthroughs were launched to fulfil it, for example, sophisticated equipment aimed at processing water or clean water that was previously polluted. These are not run smoothly because the development and urbanization in China makes China needs a decentralized solution [24]. Within this case, it can be argued that water issue have been secured, and its shortage recognized as a threat to national security of People's Republic of China. It could be argued that the process of securitization involves securitizing actors, it is dominated by the state. State performing speech act that there is an existential threat to the audience.

However, the efforts to fulfill water security which are supported by the state, achived not only from securitization in the military sense or centralized water management but also from the banking sector. A fund of 271 million RMB was disbursed with the approval of the China Securities Regulatory Commission to manage the industrialized waste-later on it is hoped that this waste can be utilized or reproduced so that it is economically advantageous [25].

In addition to investing or applying advanced technology, China also plans to reduce water use by up to $30 \%$ and is listed in the National Framework for Medium to Long-Term Food Security in 2008. The Chinese government also invests in water storage from glacial water in Xinjiang, hydroelectric dams [26]. In 2015, the Chinese government launched The Action Plan of the Prevention and Control of Water Pollution, which sets air quality that must be achieved in 2030 . This plan involving the investment around \$100.2 billion in nearly 8,000 projects only in the first half of 2017 [26]. Furthermore, in 2021, according to the Notes of the National Development and Reform Commission or the National Development and Reform Commission, the government will conduct seawater desalination. The desalination process will involve 1.25 million tons per day, including 1.05 million tons of water from coastal cities and 200,000 tons in island areas [27].

According to Yunnan Chen's writing for E-IR, Chinese officials agree that water is a strategic commodity along with food and the environment, as emphasized by Hu Jintao [28]. Wen Jiabao (1998) also said that water scarcity is considered a threat to the survival of the Chinese nation [29]. What usually happens is how securitization measures are implemented after the speech act. Chen argues that the Copenhagen School model on securitization and desecuritisation developed by Ole Waever's writings is quite suited to implement in an authoritarian country [30]. By having complete control of the public matters, the government of China does not need to persuade audiences in terms of securitization. Chen (quoting Andrew Martha) also mentions that securitization seems challenging to implement in non-authoritarian countries because decentralization allows local governments to reject and defiance [30].

\section{CONCULSION}

Water is one of the basic needs of human life. Therefore, the water crisis predicted to occur due to natural drought or industrial waste pollution can become a serious safety problem. This crisis can become a security problem because water is needed to support domestic production processes to become a source of the struggle between countries in the world. Conflicts caused by the water crisis could occur because water is a vital resource that cannot be localized or restricted to state ownership due to its dynamic nature. This potential conflict can trigger violence, leading to discussions 
about the importance of the water crisis, which tends to experience securitization issues. For this reason, UNESCO reminded the importance of cooperation between countries to reduce conflict while conserving water resources and overcoming scarcity. Gleick explained four characteristics that make water a source of strategic competition: water scarcity, meeting water needs for several countries, the relative power of governments in river institutions, and the ability to access alternative water sources. This competition can cause minor conflicts between regions or villages and even ethnic disputes over water resources.

One of the countries that implements water securitization is the Chinese government which carries out securitization because water scarcity is a consequence of economic development, namely industrialization. The securitization model is more manageable for authoritarian governments to implement because they do not have to convince people to deal with water scarcity without persuasion. Thus, the water crisis in this paper shows that the issue of securitization is a critical issue carried out by the state as the leading actor, and the audience believes that the problem is an existential threat.

\section{REFERENCES}

[6] I. Fischhendler, "The securitization of water discourse: theoretical foundations, research gaps and objectives of the special issue," Int. Environ. Agreem. Polit. Law Econ., vol. 15, no. 3, hlm. 245-255, Sep 2015, doi: 10.1007/s10784-015-9277-6.

[7] Y. Kurniawan, The Politics of Securitization in
Democratic Indonesia. Cham: Springer International Publishing, 2018. doi: 10.1007/978-3-319-62482-2.page.12

[8] Barry Buzan, Ole Waever, Jaap de Wilde. Security : A New Framework for Analysis, (London: Lynne Riener Publisher, 1998), p. 23

[9] M. C. Anthony, R. Emmers, dan A. Acharya, Ed., Non-traditional security in Asia: dilemmas in securitization. Aldershot, England; Burlington, VT: Ashgate, 2006.p.247.

http://www.unep.org/training/programmes/Inst ructor\%20Version/Part_2/Activities/Economics _of_Ecosystems/Water/Supplemental/Global_W ater_Resources.pdf

[11] http://www.wri.org/project/eutrophication/about

[12] https://databank.worldbank.org/

[14] “Andrea Ghiselli - Protecting China's Interests Overseas_ Securitization and Foreign PolicyOxford University Press (2021).pdf."

[15] Connor Dilleen. 2021. Available: https://www.aspistrategist.org.au/chinasproblematic-solution-to-its-water-security-woes/ [16] Q. Zhang, Y. Kobayashi, M. Howell Alipalo, and Y. Zheng. 2012. Drying Up: What to Do about Droughts in the People's Republic of China. Manila: ADB.

[17] 2020-DOD-CHINA-MILITARY-POWERREPORT-FINAL.pdf."

[18] Jack silvers, 2020. Water is China's Greatest Weapon and its Achilles Heel. 16 Oktober 2020, https://harvardpolitics.com/china-water-policy/

[19] Ka Ching Leung, Tackling China's Water Shortage Crisis. Climate Change. Special Report. 23 Juli 2021. Available: https://earth.org/tackling-chinas-water-shortagecrisis/

[20] Kassiola, Joel, and Guo, Sujian. 2010. China's Environmental Crisis: Domestic and Global Political Impacts and Responses, p.100

[21] http://www.forbes.com/2009/09/25/fan-fengyuchina-water-leadership-fengyu.html

http://www.meltdownintibet.com/f_redgreen.ht $\mathrm{m}$

http://www.kemira.com/en/media/whatsup/Pag es/Solutions-to-China\%E2\%80\%99s-watersecurity dewatering-and-membranetechnology.aspx

http://www.globalwaterintel.com/archive/7/8/g eneral/securitisation-comes-to-chinas-watersector.html

[25] http://www.e-ir.info/2012/06/23/thesecuritization-of-non-traditional-threats-watersecurity-in-china/ 
[26] http://www.e-ir.info/2012/06/23/thesecuritization-of-non-traditional-threats-watersecurity-in-china/

https://www.cnbcindonesia.com/news/2021060 3095337-4-250214/wah-ternyata-china-krisisair-ini-yang-dilakukan-xi-jinping

[28] China Daily, "China to step up Water Facilities Construction", 2011-07-11

[29] Scott Moore, "Climate Change, Water and China's National Interest", China Security, Vol. 5 No. 3, 2009, p.31

[30] Yunnan Chen. 2012. The Securitization of NonTraditional Threats: Water Security in China https://www.e-ir.info/2012/06/23/thesecuritization-of-non-traditional-threats-watersecurity-in-china/ 